\title{
The diversity, population, ecology and conservation status of waterbirds in the wetland of Bangpu Nature Education Center, Thailand
}

\author{
WANNA CHANATE ${ }^{1, \bullet}$, DONLA WASAN ${ }^{2}$, YOKCHOM PISARUT ${ }^{2}$, SOI-AMPORNKUL RUNGTIP ${ }^{3}$ \\ ${ }^{1}$ Department of Biology, Faculty of Science and Technology, Suan Sunandha Rajabhat University. 1 U Thong Nok Rd, Dusit, Dusit District, Bangkok \\ 10300, Thailand. Tel.: +66-2-1601143, ^email: chanate.wa@ssru.ac.th \\ ${ }^{2}$ Fish Quarantine and Inspection Division, Department of Fisheries. Lat Yao, Chatuchak, Bangkok 10900, Thailand \\ ${ }^{3}$ Department of Biochemistry, Faculty of Medicine Siriraj Hospital, Mahidol University. 2 Thanon Wang Lang, Siri Rat, Bangkok Noi, Bangkok 10700,
} Thailand

Manuscript received: 25 July 2020. Revision accepted: 31 July 2020.

\begin{abstract}
Chanate W, Wasan D, Pisarut Y, Rungtip S. 2020. The diversity, population, ecology, and conservation status of waterbirds in the wetland of Bangpu Nature Education Center, Thailand. Biodiversitas 21: 3910-3918. Wetlands are a crucial habitat for waterbirds as they provide feeding and breeding sites and increase survival rates during the non-breeding season. This study aimed to update the status of waterbirds in Bangpu Nature Education Center, Samut Prakarn Province, Thailand by evaluating the species diversity and abundance. The ground count survey was conducted at 3 habitats: mangrove forest, mudflat, and bungalow accommodation from March to October 2017. A total of 34 waterbird species classified under 5 orders, 8 families, and 22 genera were observed. The majority of waterbird species (23 species) were found in the mudflat area with the least number (12 species) observed in the bungalow accommodation location. The Shannon-Weiner diversity index (H') showed that the mudflat area had significantly greater diversity compared with the other sites. The mudflat area also had the greatest species richness (D) (2.89) and species evenness index (E) (0.38), respectively. The Sorensen similarity index (CS) indicated that the greatest similarity in species (66.67\%) was found between the mangrove and bungalow areas. A total of 6 residents, 20 migratory species, and 8 species with both resident and migratory populations were found with 4 species classified as abundant, 3 as common, 15 as moderately common, and 12 as uncommon species identified. In addition, the conservation status of waterbirds is becoming increasingly important with 5 near-threatened species (NT) already identified according to IUCN, 2016 and Red Data of Thailand, 2007, consisting of Heteroscelus brevipes, Limosa limosa, Numenius arquata, Mycteria leucocephala and Vanellus cinereus. It is recommended that monitoring the conservation status of the Bangpu wetlands should be continued to maintain waterbird diversity.
\end{abstract}

Keywords: Biodiversity, Bangpu Nature Education Center, conservation status, near-threatened, waterbirds, wetland

\section{INTRODUCTION}

Wetlands are informally known as "biological supermarkets" as they provide some of the most productive and biologically diverse living organisms in the world, yet they are also recognized as very fragile ecosystems (Zedler and Kercher 2005). One of the biological elements living in wetland ecosystems is waterbirds. There is a great variety of wetland ecosystems that have allowed different adaptation and wetland utilization across waterbird species (Dahl and Johnson 1991). The ecological quality of wetlands is directly correlated with the diversity and abundance of waterbird species, meaning that an increase in bird numbers indicates a good wetland ecosystem (Dugan 1990; Stewart 2007).

Waterbirds are crucial bioindicators for assessing the ecological condition and productivity of wetlands, as they occupy several trophic levels in the food web of wetland nutrient cycles (Scott 1980; Fernández et al. 2005). They inhabit, or temporally use wetlands, for breeding, nesting and resting, and are particularly attracted by the food richness in the water (Stewart 2007). While natural wetlands support numerous resident and migrant waterbirds (Ismail et al. 2012), the population of residential and migrant waterbirds are reported to have declined significantly (Wetland International 2012). The destruction of wetland areas, due to various human activities and/or climatic change, is a significant threat to waterbird species diversity and abundance throughout the world (Mckinney 2002), with some waterbirds are no longer documented in several wetlands (Wetlands International 2012).

The Bangpu Nature Education Center was established in 1947 to be located on the south coast of Samut Prakan Province, which is an ecosystem dominated by mangrove forests and mudflats, which leads to the waters of the Gulf of Thailand. In partnership with the Royal Thai Army, it was developed as Thailand's first urban nature education center. The reduction of waterbird diversity globally has increased worldwide attention, leading to the Bangpu wetland becoming a designated Ramsar conservation area habitat of waterbirds; a wetland of international significance. The role of the center is to maintain the conservation of the wetlands alongside to provide nature education (John et al. 2012). This area is also aimed to promote the importance of coastal mangrove forests, as both breakwaters between the sea and the land, and as the essential nesting grounds of many coastal birds and other sea creatures. Furthermore, the existing site is recognized as an attraction for migrating birds, harboring some 160 species, including many globally endangered species 
(WWF 2007).

This area was previously studied by Kamnung and Suppadit (2015) who investigated the correlation of environmental factors such as water level of the area, sea level, temperature, relative humidity and rainfall that affect species and population of waterbirds in the same area of this study. Despite the high diversity of bird species in the Bangpu area, information on waterbird species in the area is not comprehensive, and the lack of scientific information on the ecology and conservation status of waterbirds in the Bangpu so that we see the knowledge gaps. Thus, our study was the first to reveal the population trends of waterbirds in different duration and provide opportunities to strengthen waterbirds conservation in wetlands of this area. Moreover, the Bangpu is located in an industrial area which has resulted in severe water pollution, causing pressure to threatened species (Landesman 1994). Therefore, since waterbird diversity, abundance, distribution, and activities, reflect the ecosystem quality and status, it is necessary to assess and monitor present waterbird populations (Ismail et al. 2012).

To understand the current status of waterbirds in the Bangpu wetlands, this study aimed to analyze the species diversity, status, and distribution of waterbirds around the
Bangpu Nature Education Center. The results from this study can be used for comparative tracking and monitoring of biodiversity at the local and national level, and help contribute to realizing the importance of waterbirds on ecosystems. In addition, the results can serve as baseline information to study the changes in the conservation of waterbirds in the future.

\section{MATERIALS AND METHODS}

\section{Study area}

The Bangpu Nature Education Center is located on the south coast of Samut Prakan Province, Thailand, and is adjacent to the Gulf of Thailand and the Chao Phraya River Estuary $\left(3^{\circ} 30^{\prime} 32.07^{\prime \prime} \mathrm{N}, 100^{\circ} 41^{\prime} 51.96^{\prime \prime} \mathrm{E}\right)$. It has a total area of 639 hectares, which is divided into 301 hectares of recreational area and 338 hectares of nature study area (Bangpu Nature Education Center 2013). The survey was conducted in three areas, including a mangrove forest (zone A), mudflat (zone B), and water area at the bungalow accommodation (zone C) (Figure 1).

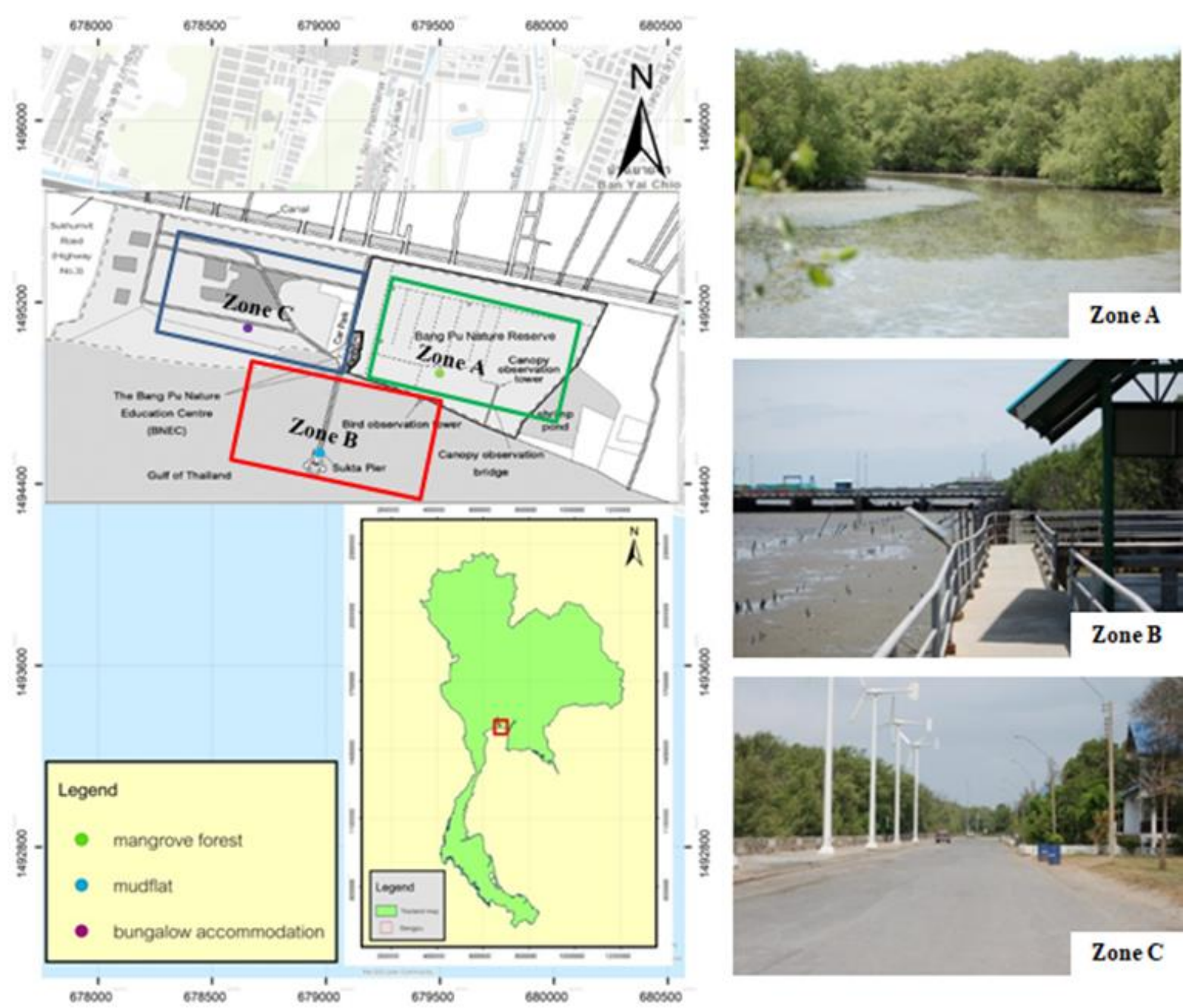

Figure 1. Map and the landscape condition of three survey areas in Bangpu Nature Education Center, Samut Prakarn, Thailand 


\section{Waterbirds survey and sampling method}

In order to assess the diversity, abundance and the status of waterbirds in the Bangpu wetlands along with the important habitats used by the waterbirds, this study was carried out for data collection using the ground count method in accordance with the Birds Conservation Society of Thailand \& Department of National Parks, Wildlife and Plant Conservation (2012) and was done twice a month from March to October 2017. The survey was conducted at 2 periods, 07.00 to $10.00 \mathrm{am}$, and 13.00 to $16.00 \mathrm{pm}$. Direct observations were made using binoculars $(40 \mathrm{x} \quad 42$ magnification power) and a camera.

The method to observe waterbirds at different habitats was adjusted according to locations and remoteness of the wetlands. The survey of waterbirds community was conducted by moving along the trails, which were divided into mangrove forests, mudflat, and bungalow accommodation. In each survey, the waterbird species diversity and abundance, morphology, habitat, duration, and activities like feeding, flying, resting, etc. were also recorded. For further identification purposes, the waterbirds were photographed the field itself. Each observed species in the study was identified using field guide for Thailand (Lekagul and Round 2006) and a field guide for South-East Asia (King et al. 1975). This study was approved and carried out following the principles of the Basel Declaration and recommendations of the Birds Conservation Society of Thailand \& Department of National Parks, Wildlife and Plant Conservation.

\section{Data analysis}

The measurement of relative abundance, species richness, species diversity, species evenness, and similarity index, were used to quantify biological diversity.

The relative abundance (RA) of waterbirds in each area was assessed using the formula of Pettingil (1969), i.e. by dividing the number of individuals of a species by the total number of waterbirds observed and multiplying the quotient by 100 to make it a percentage. The relative abundance in the study area was grouped into 5 categories: i.e. Abundant (90-100\%); Common (65-89\%); Moderately Common (3164\%); Uncommon (10-30\%) and Rare (1-9\%).

Species richness (D) in each area was assessed using the formula of Ludwig and Reynold (1988):

$$
\mathrm{D}=\left(\mathrm{N}_{\mathrm{o}}-1\right) / \mathrm{ln} \mathrm{N}
$$

Where; $\mathrm{N}_{\mathrm{o}}$ : number of observed species in each area and $\mathrm{N}$ : total number of individuals in each area

The Shannon-Weiner Diversity Index (H') was calculated for each area using the formula of Ludwig and Reynold (1988):

$$
\mathrm{H}^{\prime}=\sum_{\mathrm{i}=1}^{\mathrm{N}}\left[\mathrm{p}_{\mathrm{i}}\left(\ln \mathrm{p}_{\mathrm{i}}\right)\right]
$$

Where; $p_{i}$ : number of observed individuals of the $i^{\text {th }}$ species divided by the total number of all waterbirds.

Species evenness index (E) was used to assess the relative abundance of the different species making up the richness of an area. It compares the similarity of the population size of each of the species present using Pielou's evenness index (Ludwig and Reynold, 1988).

$$
\mathrm{E}=\mathrm{H}^{2} / \ln \mathrm{N}
$$

Where, species diversity index divided by In of total number of individuals in each area.

Sorensen similarity index (CS) was used to compare the same waterbird species in different areas (Lekagul and Round 2006) and formulated as follows:

$$
\mathrm{CS}=2 \mathrm{a} /(2 \mathrm{a}+\mathrm{b}+\mathrm{c})
$$

Where; a: number of waterbird species found in both areas, $b$ : number of waterbird species found only in area $B$ and c: number of waterbird species found only in area $\mathrm{A}$.

\section{The assessment of waterbirds status}

The checklist was prepared by analyzing the current conservation and seasonal status of the waterbirds (Lekagul and Round, 2006) and divided into 6 groups: (i) resident, (ii) winter visitor, (iii) passage migrant, (iv) breeding visitor, (v) vagrant, and (vi) resident and migrant. The Wildlife Conservation and Protection Act (2003) was used to classify the waterbirds as follows: (i) wildlife reserve, (ii) wildlife protection, and (iii) wildlife outside protection. The International Union for Conservation of Nature Redlist [IUCN] (2016) and the Red Data of Thailand (2007) was used to classify the waterbirds conservation status as Extinct (EX), Extinct in the Wild (EW), Critically Endangered (CR), Endangered (EN), Vulnerable (VU), Conservation Dependent (CD), Near Threatened (NT), Least Concern (LC), or Data Deficient (DD).

\section{RESULTS AND DISCUSSION}

\section{Species diversity of waterbirds in Bangpu wetlands}

A total number of 3,375 individuals were observed, consisting of 34 species belonging to 22 genera under 8 families distributed in 5 orders. There were 21 species and 1,851 individuals in mangrove, 23 species and 1,428 individuals in mudflat, and 12 species and 96 individuals in bungalow accommodation areas (Table 1). Among the waterbirds recorded, the Family Scolopacidae had the highest number of waterbird species present (10 species), followed by the Ardeidae ( 8 species), Charadriidae (6 species), Laridae (4 species), Ciconiidae and Phalacrocoracidae (2 species each) and Recurvirostridae and Rallidae (1 species each) (Figure 2).

The greatest species richness (2.89), species diversity (1.29) and species evenness (0.38) were observed in the mudflat area compared to the other locations (Table 1). This may have resulted from the overall species diversity increases as the greatest number of species was observed in the mudflat area. Nevertheless, the similarity index was $64.29 \%$, with the number of waterbird species different was observed between the mudflat (zone B) and bungalow (zone C) areas. These findings suggest that both areas had a different waterbird species composition due to a disturbance in zone $\mathrm{C}$ (Table 1). 
Table 1. The biological diversity of waterbirds in three habitat areas in Bangpu Nature Education Center, Samut Prakarn in MarchOctober 2017.

\begin{tabular}{lccc}
\hline \multicolumn{1}{c}{ Biological diversity index } & $\begin{array}{c}\text { Mangrove forest } \\
\text { (zone A) }\end{array}$ & $\begin{array}{c}\text { Mudflat } \\
\text { (zone B) }\end{array}$ & $\begin{array}{c}\text { Bungalow } \\
\text { accommodation (zone C) }\end{array}$ \\
\hline Number of individuals & $1,851^{\mathrm{c}}$ & $1,428^{\mathrm{b}}$ & $96^{\mathrm{a}}$ \\
Number of species & 21 & 23 & 12 \\
Species richness index (D) & $2.39^{\mathrm{b}}$ & $2.89^{\mathrm{c}}$ & $2.19^{\mathrm{a}}$ \\
Species diversity index (H') & $0.98^{\mathrm{b}}$ & $1.29^{\mathrm{c}}$ & $0.16^{\mathrm{a}}$ \\
Species evenness index (E) & $0.29^{\mathrm{b}}$ & $0.38^{\mathrm{c}}$ & $0.05^{\mathrm{a}}$ \\
Sorensen similarity index (CS) & & & \\
- Zone A and B & & $65.00 \%$ & $66.67 \%$ \\
- Zone A and C & & $64.29 \%$ & \\
- Zone B and C & & \\
\hline
\end{tabular}

Note: Different letters in the row indicate significant differences at $p<0.05$.
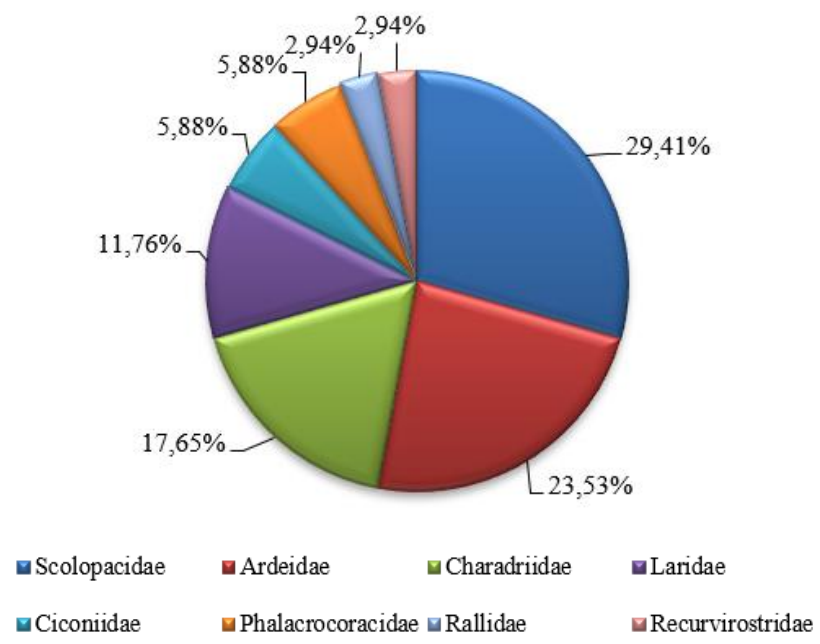

Figure 2. The proportion of waterbird species in each family observed in Bangpu Nature Education Center, Samut Prakarn, Thailand

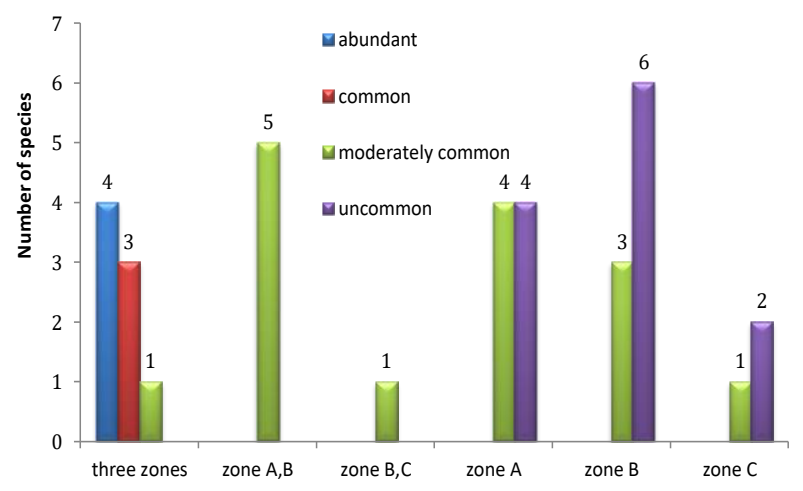

Figure 3. Species richness of waterbird species in three habitat areas in Bangpu Nature Education Center, Samut Prakarn, Thailand in March-October 2017

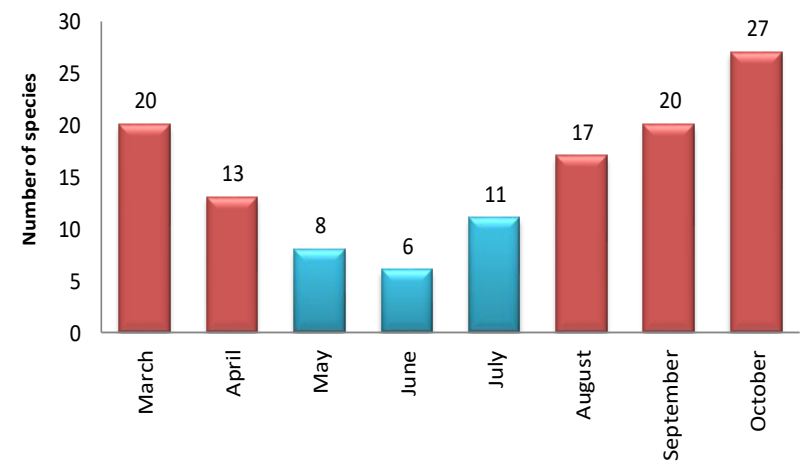

Figure 4. Number of waterbird species found from March to October 2017 in Bangpu Nature Education Center, Samut Prakarn, Thailand. Note: $\square$ : the migratory season, $\square$ : the nonmigratory season

\section{Species abundance of waterbirds}

The most abundant species status was recorded as moderately common. There were only 8 waterbird species found at the mangrove, 9 species at the mudflat, and 3 species at the bungalow accommodation areas. Five waterbird species were found at both the mangrove forest and mudflat sites (Figure 3). Four waterbird species, including the Black-winged Stilt, Great Egret, Javan Pond Heron, and Little Cormorant, were classified as highly abundant, whereas the Lesser Sand Plover, Painted Stork, and Little Egret were common, and found in all areas. The remaining species had an uncommon abundance (Table 2).

\section{The seasonal status of waterbirds}

Waterbird diversity was greatest during the migratory season (March-April, and August-October) compared with the non-migratory season (May-July). The number of waterbird species was the highest in October (27 species), as this period included the breeding season of residents and some migration to the study area. Some waterbirds foraged and dispersed away from the study area in the rainy season, and had the effect of decreasing the number of species, as shown in Figure 4. Using the Lekagul and Round (2006) method to assess the seasonal status of waterbirds, we found that there were 6 residents, 20 winter visitors and 8 residents and migrants, respectively (Table 3 ). 
Table 2. List of taxonomic and abundant status of waterbirds recorded in three habitat areas in Bangpu Nature Education Center, Samut Prakarn in March-October 2017

\begin{tabular}{|c|c|c|c|c|}
\hline Order/family & Scientific name & Common name & Abundance & Area \\
\hline \multicolumn{5}{|l|}{ Charadriiformes } \\
\hline \multirow[t]{6}{*}{ Charadriidae } & Charadrius dubius & Little Ringed Plover & $\mathrm{MC}$ & $a, b$ \\
\hline & Charadrius leschenaultii & Greater Sand Plover & UC & $\mathrm{b}$ \\
\hline & Charadrius mongolus & Lesser Sand Plover & $\mathrm{C}$ & $\mathrm{a}, \mathrm{b}, \mathrm{c}$ \\
\hline & Pluvialis fulva & Pacific Golden Plover & MC & $a, b$ \\
\hline & Vanellus cinereus & Grey-headed Lapwing & $\mathrm{UC}$ & $\mathrm{a}$ \\
\hline & Vanellus indicus & Red-wattled Lapwing & UC & $\mathrm{a}$ \\
\hline \multirow[t]{4}{*}{ Laridae } & Chlidonias hybridus & Whiskered Tern & $\mathrm{MC}$ & $\mathrm{b}, \mathrm{c}$ \\
\hline & Chlidonias leucopterus & White-winged Tern & $\mathrm{UC}$ & $\mathrm{b}$ \\
\hline & Larus brunnicephalus & Brown-headed Gull & $\mathrm{MC}$ & $\mathrm{b}$ \\
\hline & Larus ridibundus & Black-headed Gull & $\mathrm{MC}$ & $\mathrm{b}$ \\
\hline Recurvirostridae & Himantopus himantopus & Black-winged Stilt & A & $\mathrm{a}, \mathrm{b}, \mathrm{c}$ \\
\hline \multirow[t]{10}{*}{ Scolopacidae } & Actitis hypoleucos & Common Sandpiper & UC & $\mathrm{c}$ \\
\hline & Arenaria interpres & Ruddy Turnstone & UC & $\mathrm{b}$ \\
\hline & Heteroscelus brevipes & Grey-tailed Tattler & UC & $\mathrm{b}$ \\
\hline & Limosa limosa & Black-tailed Godwit & $\mathrm{MC}$ & $a, b$ \\
\hline & Numenius arquata & Eurasian Curlew & $\mathrm{UC}$ & $\mathrm{a}$ \\
\hline & Numenius phaeopus & Whimbrel & UC & $\mathrm{b}$ \\
\hline & Tringa glareola & Wood Sandpiper & MC & $\mathrm{a}$ \\
\hline & Tringa nebularia & Common Greenshank & $\mathrm{MC}$ & $\mathrm{a}$ \\
\hline & Tringa stagnatilis & Marsh Sandpiper & $\mathrm{MC}$ & $a, b$ \\
\hline & Tringa tetanus & Common Redshank & MC & $a, b$ \\
\hline \multicolumn{5}{|l|}{ Ciconiiformes } \\
\hline \multirow[t]{2}{*}{ Ciconiidae } & Anastomus oscitans & Asian Openbill & MC & $\mathrm{b}$ \\
\hline & Mycteria leucocephala & Painted Stork & $\mathrm{C}$ & $\mathrm{a}, \mathrm{b}, \mathrm{c}$ \\
\hline \multicolumn{5}{|l|}{ Gruiformes } \\
\hline Rallidae & Amaurornis phoenicurus & White-breasted Waterhen & MC & $\mathrm{c}$ \\
\hline \multicolumn{5}{|l|}{ Pelecaniformes } \\
\hline \multirow[t]{8}{*}{ Ardeidae } & Ardea alba & Great Egret & A & $\mathrm{a}, \mathrm{b}, \mathrm{c}$ \\
\hline & Ardea cinerea & Grey Heron & $\mathrm{MC}$ & $\mathrm{a}$ \\
\hline & Ardeola bacchus & Chinese Pond Heron & $\mathrm{UC}$ & $\mathrm{a}$ \\
\hline & Ardeola speciosa & Javan Pond Heron & A & $\mathrm{a}, \mathrm{b}, \mathrm{c}$ \\
\hline & Butorides striatus & Striated Heron & $\mathrm{MC}$ & $\mathrm{a}, \mathrm{b}, \mathrm{c}$ \\
\hline & Egretta garzetta & Little Egret & $\mathrm{C}$ & $\mathrm{a}, \mathrm{b}, \mathrm{c}$ \\
\hline & Ixobrychus sinensis & Yellow Bittern & UC & $\mathrm{c}$ \\
\hline & Mesophoyx intermedia & Intermediate Egret & $\mathrm{MC}$ & $\mathrm{a}$ \\
\hline \multicolumn{5}{|l|}{ Suliformes } \\
\hline \multirow[t]{2}{*}{ Phalacrocoracidae } & Phalacrocorax fuscicollis & Indian Cormorant & $\mathrm{UC}$ & $\mathrm{b}$ \\
\hline & Phalacrocorax niger & Little Cormorant & A & $\mathrm{a}, \mathrm{b}, \mathrm{c}$ \\
\hline
\end{tabular}

Note: Abundances criteria: A: Abundance, C: Common, MC: Moderately Common, UC: Uncommon, R: Rare, Area: a: Mangrove forest; b: Mudflat and c: Bungalow accommodation

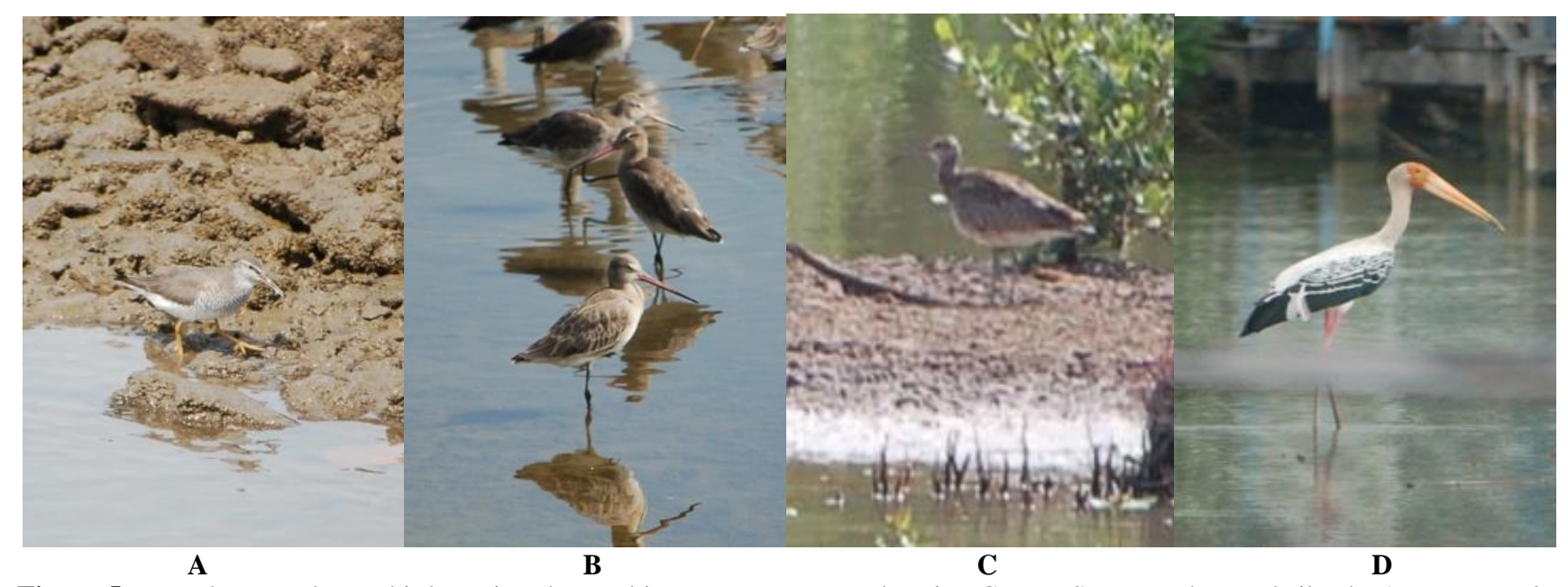

Figure 5. Near-threatened waterbird species observed in Bangpu Nature Education Center, Samut Prakarn, Thailand: A. Heteroscelus brevipes, B. Limosa limosa, C. Numenius arquata, D. Mycteria leucocephala 
Table 3. The status of residential and conservation concerns of waterbirds in Bangpu Nature Education Center, Samut Prakarn, Thailand

\begin{tabular}{|c|c|c|c|c|}
\hline \multirow{2}{*}{$\begin{array}{l}\text { Scientific name } \\
\text { Charadrius dubius }\end{array}$} & \multirow{2}{*}{$\begin{array}{c}\begin{array}{c}\text { Residential } \\
\text { status }^{1}\end{array} \\
\mathrm{R} / \mathrm{M}\end{array}$} & \multicolumn{3}{|c|}{$\begin{array}{l}\text { Conservation status } \\
\text { Act }^{2} \text { ONEP }^{3} \text { IUCN }\end{array}$} \\
\hline & & $\mathrm{P}$ & - & LC \\
\hline Charadrius leschenaultii & WV & $\mathrm{P}$ & - & $\mathrm{LC}$ \\
\hline Charadrius mongolus & WV & $\mathrm{P}$ & - & $\mathrm{LC}$ \\
\hline Pluvialis fulva & WV & $\mathrm{P}$ & - & $\mathrm{LC}$ \\
\hline Vanellus cinereus & WV & $\mathrm{P}$ & NT & $\mathrm{LC}$ \\
\hline Vanellus indicus & $\mathrm{R}$ & $\mathrm{P}$ & - & $\mathrm{LC}$ \\
\hline Chlidonias hybridus & WV & $\mathrm{P}$ & - & $\mathrm{LC}$ \\
\hline Chlidonias leucopterus & WV & $\mathrm{P}$ & - & $\mathrm{LC}$ \\
\hline Larus brunnicephalus & WV & $P$ & - & $\mathrm{LC}$ \\
\hline Larus ridibundus & WV & $\mathrm{P}$ & - & $\mathrm{LC}$ \\
\hline Himantopus himantopus & $\mathrm{R} / \mathrm{M}$ & $\mathrm{P}$ & - & $\mathrm{LC}$ \\
\hline Actitis hypoleucos & WV & $\mathrm{P}$ & - & $\mathrm{LC}$ \\
\hline Arenaria interpres & WV & $\mathrm{P}$ & - & $\mathrm{LC}$ \\
\hline Heteroscelus brevipes & WV & $\mathrm{P}$ & - & NT \\
\hline Limosa limosa & WV & $\mathrm{P}$ & - & NT \\
\hline Numenius arquata & WV & $\mathrm{P}$ & - & NT \\
\hline Numenius phaeopus & WV & $\mathrm{P}$ & - & $\mathrm{LC}$ \\
\hline Tringa glareola & WV & $\mathrm{P}$ & - & $\mathrm{LC}$ \\
\hline Tringa nebularia & WV & $\mathrm{P}$ & - & $\mathrm{LC}$ \\
\hline Tringa stagnatilis & WV & $\mathrm{P}$ & - & LC \\
\hline Tringa tetanus & WV & $\mathrm{P}$ & - & $\mathrm{LC}$ \\
\hline Anastomas oscitans & $\mathrm{R}$ & $\mathrm{P}$ & - & $\mathrm{LC}$ \\
\hline Mycteria leucocephala & $\mathrm{R} / \mathrm{M}$ & $\mathrm{P}$ & - & NT \\
\hline Amaurornis phoenicurus & $\mathrm{R}$ & $\mathrm{P}$ & - & $\mathrm{LC}$ \\
\hline Ardea alba & $\mathrm{R} / \mathrm{M}$ & $\mathrm{P}$ & - & $\mathrm{LC}$ \\
\hline Ardea cinerea & $\mathrm{R} / \mathrm{M}$ & $\mathrm{P}$ & - & $\mathrm{LC}$ \\
\hline Ardeola bacchus & WV & $\mathrm{P}$ & - & $\mathrm{LC}$ \\
\hline Ardeola speciosa & $\mathrm{R}$ & $\mathrm{P}$ & - & $\mathrm{LC}$ \\
\hline Butorides striatus & $\mathrm{R} / \mathrm{M}$ & $\mathrm{P}$ & - & $\mathrm{LC}$ \\
\hline Egretta garzetta & $\mathrm{R} / \mathrm{M}$ & $\mathrm{P}$ & - & $\mathrm{LC}$ \\
\hline Ixobrychus sinensis & $\mathrm{R} / \mathrm{M}$ & $\mathrm{P}$ & - & $\mathrm{LC}$ \\
\hline Mesophoyx intermedia & WV & $\mathrm{P}$ & - & $\mathrm{LC}$ \\
\hline Phalacrocorax fuscicollis & $\mathrm{R}$ & $\mathrm{P}$ & - & $\mathrm{LC}$ \\
\hline Phalacrocorax niger & $\mathrm{R}$ & $\mathrm{P}$ & - & $\mathrm{LC}$ \\
\hline
\end{tabular}

Note: ${ }^{1}$ Residential status, following Lekagul and Round (2006): $\mathrm{R}$ : resident; WV: winter visitor; PM: passage migrant; $\mathrm{BV}$ breeding visitor; $\mathrm{V}$ : vagrant and $\mathrm{R} / \mathrm{M}$ : resident and migrant. ${ }^{2}$ Status based on the Wildlife Reservation and Conservation Act (2003): P: protected species and N: none. ${ }^{3}$ Status based on the Wildlife Thai Red List (2007): NT: near-threatened species. ${ }^{4}$ Status based on the International Union for Conservation of Nature (IUCN, 2016): NT: near-threatened and LC: least concern species.

\section{The conservation status of waterbirds}

According to Wild Animal Reservation and Protection Act (2003), the conservation status of the waterbirds in this study were all classified as a protected species. Our research also indicated that Grey-tailed Tattler, Blacktailed Godwit, Eurasian Curlew, and Painted Stork were classified as a near-threatened waterbird species, as shown in Figure 5.A-D. Conforming with the IUCN (2016), the Grey-tailed Tattler (Heteroscelus brevipes), Eastern Blacktailed Godwit (Limosa limosa), Eurasian Curlew (Numenius arquata) and Painted Stork (Mycteria leucocephala) had a near-threatened status (NT). The other 30 species were classified as least concern (LC) (Table 3).

\section{Discussion}

In our survey, 34 species belonging to 8 families and 5 orders of waterbirds were detected, suggesting the Bangpu wetland provides a suitable habitat for waterbirds. Moreover, the species diversity and abundance, migration status, and ecological types suggest that the site is an important waterbird breeding, stopover and wintering site.

In terms of species diversity, the Bangpu wetland is important to the waterbird community, possibly because of the shallower and slower running wetland hydrology within the area. Indeed, the mudflat and mangrove areas are important foraging areas in the Bangpu wetland as they are sheltered by the macrophytes. Our results are similar to other studies of waterbird diversity in Asian wetlands (Zou et al. 2008; Mardiastuti et al. 2016). Interestingly, the number of waterbird species in the mudflat area was similar to the mangrove, possibly due to the two areas supporting similar prey-bases. In addition, the mudflat also supports substantial populations of shellfish, other crustaceans, and benthic fauna (WWF 2007). In consideration of the time of the year for each area, the sea level in the mangrove forest and bungalow accommodation areas has been shown to have a negative correlation with waterbird species and populations (Kamnung and Suppadit 2015), so seasonal and diurnal patterns of tides affect waterbird diversity and abundance.

The Bangpu wetland is dominated by mangrove and mudflat habitats with fifty-three plant species having been recorded within these sites (John et al. 2012). Petersen and Westmark (2013) found that bird species richness and diversity were positively correlated with vegetation structure, vegetation composition, and productivity in wetlands of Midwestern Metropolitan. In agreement, we observed a lower number of waterbird individuals around the bungalow accommodation area. The different strata of vegetation and greater abundance of invertebrates have attracted different waterbird species to select wetland areas for foraging, safe breeding sites, and as cover from predators (Fairbairn and Dinsmore 2001; Kostecke et al. 2005). The Bangpu wetland plays an important role as a stopover and breeding site for migratory birds, therefore there is a higher number of species in the mudflat and mangrove areas during migration compared to during the breeding period. Similarly, this is characterized by a higher proportion of migratory waterbirds compared with resident birds (Park et al. 2012; Jae-Pyoung et al. 2013). Moreover, the extremely high density of breeding at this site has caused an overall increase in species diversity, with the mudflat habitat being attributed to having greater resources, such as food and nesting sites, resulting in supporting more waterbirds (Remsen and Parker 1983; Walwert et al. 2004). Accordingly, several reports have indicated that the diversity of birds increases as the size of habitat is increasing (Marsden et al. 2001; Cook et al. 2002; Chaiyes et al. 2009).

The biological diversity of waterbirds was greater in the mangrove and mudflat sites compared with the bungalow accommodation area. The species richness is highly influenced by the landscape and regional species pools 
(Gaston, 2000), with structurally complex landscapes supporting more species than simple landscapes. Besides, the conversion of native ecosystems to annual crops may lead to a decline in the richness of waterbirds, because the species richness is negatively correlated with agricultural expansion and changed land-use practices (Schrag et al. 2009). Furthermore, forested habitats with dense native vegetation cover are effective for the conservation of forest and endemic avifauna (Lee et al. 2007). Nguyen et al. (2009) found that the hydrological conditions in the Tram Chim National Park, Dong Thap Province, Vietnam exerted a strong influence upon the wetland grassland structures, including vegetation communities and the fauna, which could support waterbirds by providing roosting, foraging and breeding areas.

In all three studied sites, the abundant status of the waterbirds was found to be mainly classified as either moderately common or uncommon species. These species abundances appear to be better adapted for exploiting the resources of these wetlands, and rise with an increase in food availability (Welsh 1987). The distribution and abundance of many waterbirds are determined by the composition of the vegetation, which forms the major element of their habitats. The abundance of waterbird species depended significantly on the vegetation characteristics, indicating that areas with high plant resources supported more birds. Thus, the relatively low abundance of waterbirds could be attributed to the destruction of wetland habitats. As vegetation changes along complex geographical and environmental gradients, a particular waterbird species may decrease in number and disappear as the habitat changes (Lee and Rotenberry 2005; Chapman and Reich, 2007; Salah and Idris 2013). The abundance of waterbird species is influenced by many factors, including habitat size, trophic status, aquatic macrophytes (Hoyer and Canfield 1994; Hattori and Mae 2001; Tavares and Siciliano 2014), water/mud depth or sea level (Hattori and Mae 2001), season (Tavares and Siciliano 2014), temperature and humidity (Briggs and Holmes 1988), and the disturbance to the habitat (Nichols and Thompson 1985). It has also been reported that climatic conditions play an important role in the diversity and abundance of waterbirds. In the Pulau Rambut Wildlife Sanctuary in Jakarta Bay, Indonesia, strong winds have a high impact on the nest site selection of waterbirds (Mardiastuti 1992), with the abundance of waterbirds negatively associated with the maximum wind speed in Lousiana, USA (Leberg et al. 2007).

The present findings, related to the seasonal status of waterbirds, were compared to an investigation of birds at Thale Noi of southern Thailand and suggested that the bird populations were low from July to October. However, there were greater bird populations in the period from October to December at Khuan Nang Whean and Khuan Thale Mong (Angkapreechases 1985). The majority of waterbirds observed during this study were winter visitors because they used the wetland areas for resting, and other activities, while waiting for the return of favorable conditions at their home range. Furthermore, these areas have plenty of invertebrates, which are food sources for migratory waterbirds (Lameed 2011; Charoenpokaraj et al. 2017). The waterbird species found in the wetlands need specific areas to carry out reproductive activities, especially nesting sites (Hansen et al. 2005). The winter season is expected to have a higher ratio of waterbird composition, richness, and abundance due to its microclimate and microhabitat structure (Andrei et al. 2009). In addition, it is well known that environmental quality may affect the equilibrium of the wildlife population size (Varasteh and Zakaria 2009), richness, and abundance of species (Zou et al. 2008). Therefore, the waterbirds would respond quickly to any change in their habitat. The abundance of waterbirds at the study sites fluctuated seasonally depending on the interaction between species and habitat, thus they can be used as a key tool for monitoring the change in degradation in this area (Liang et al. 2002). Most of the migratory waterbirds in Thailand use the East Asian Australasian Flyway, which starts from the Arctic and continues to Southeast Asia, Australia, and New Zealand (Erftemeijer and Jugmongkol 1999). The migration of birds is an important part in their circle of life among season changes, with most birds migrating to places plentiful in foods, by heading south to the tropical regions and migrating back home for nesting when the winter ceases (Jukmongkol 2002; Kober 2004).

Our results are consistent with Charoenpokaraj et al. (2017) who reported an almost identical near-threatened species in the salt fields and aquaculture areas along with the coastal land at Bang Kaew, Samut Songkhram Province, Thailand. These waterbird species are attractive to birders and tourists interested in birding activity, as the research area in the Bangpu Nature Education Centre is a Ramsar site that has vegetation cover. This attracts most birds due to the available food, shelters and breeding sites (Scott 1997; John et al. 2012). Moreover, these research areas are valuable as birding sites because a group of local people have worked to protect the mangrove and birding foraging areas. This has enabled them to become local guides for bird watchers, with provision of accommodation for tourists. This has led to some waterbird groups in the tourist area at the seasonal evergreen forest having a negative correlation with human activities. The similarity, diversity and density indices are therefore an indicator for conservation and management strategies of avifauna (Nakwa et al. 2008). Public awareness has been the best instrument for the conservation and change of human attitudes and behavior patterns towards the mangrove forests (Ghasemi et al. 2010). Thus, the measurement of biodiversity is a fundamental process for the conservation and management of natural ecosystems (Humphries et al. 1995). The decrease in the number of organisms via pollution, habitat conversion, and environmental degradation, which is caused by human activities, may lead to a diversity crisis in natural habitats (Novacek and Wheeler 1992; Sisk et al. 1994).

For instance, waterbirds concentrate significantly in mudflat areas, showing a high dependence on this habitat (Clemens et al. 2014; Murray and Fuller 2015). In the present study, there was a positive relationship between the number of waterbirds, the habitat types, and the utilization 
within that habitat. This may provide an explanation of why low disturbed areas have a high species richness, diversity, abundance, and distribution of waterbirds. All of the habitats used by a bird play a role in its survival, consequently, the loss or degradation in any of them, can potentially have a population-level impact. It is habitat loss that is the greatest threat to waterbirds, and may also result in wetland degradation, driving some birds to seek new habitats (Ma et al. 2002). It is concluded that the abundance of waterbird species depends on food availability and suitable habitats.

It was conclusively shown that the Bangpu Nature Education Center is an important habitat for supporting waterbirds in wetlands, whereas the protected areas have been partly converted to human settlements. The large numbers of waterbirds occurred in habitats providing food in the mudflat and mangrove areas. The difference in species composition and diversity in the three different habitats reflect the ecosystem complexity and suitability that changes over time. A variety of habitats and environments attract and support a variety of waterbird species, decreasing the waterbirds diversity and thereby destroying the entire wetland ecosystem. The continuous monitoring of avian fauna is an excellent means of monitoring wetland health, helping the sustainable improvement of the habitat in this area. Therefore, public awareness should be provided to help ensure the protection and conservation of the wetlands to protect bird habitats. The application of proper management programs and strategies will not only increase the number of resident waterbird species but will also attract migratory and vagrant species. Finally, these results provide an updated report related to the avifauna dynamics at the Bangpu Nature Education Center.

\section{ACKNOWLEDGEMENTS}

The authors would like to express their gratitude to the National Council of Thailand for the full funding support of this research project. We would also like to acknowledge Bangpu Nature Education Center for helping in the surveyed area and Suan Sunandha Rajabhat University, Bangkok, Thailand, for all the necessary support.

\section{REFERENCES}

Andrei A, Smith L, Haukos D, Surles J, Johnson W. 2009. Foraging ecology of migrant shorebirds in Saline Lakes of the Southern Great Plains. Waterbirds 3 2(1): 138-148.

Angkapreechases P. 1985. Population dynamics of birds at Thale Noi nonhunting area. [Thesis]. Graduate School, Bangkok, Kasetsart University, Thailand.

Bangpu Nature Education Center. 2013. Introduction to Bangpu Nature Education Center. Bangpu Nature Education Center, Samut Prakan, Thailand.

Bird Conservation Society of Thailand \& National Parks, Wildlife and Plant Conservation. 2012. Asian Waterbird Census Thailand 2012, Bangkok.

Briggs SV, Holmes JE. 1988. Bag size of waterfowl research in New South Wales and their relation antecedent rainfall. Australian Wildlife Res 15: 459-468.
Chaiyes A, Duengkae P, Wongwai A, Pratumthong D. 2009. Influences of patch sizes on bird assemblages around western forest complex of Thailand. Thai J For 28 (2): 1-12.

Chapman KA, Reich PB. 2007. Land use and habitat gradients determine bird community diversity and abundance in suburban, rural and reserve landscapes of Minnesota, USA. Biol Conserv 135: 527-541.

Charoenpokaraj N, Chitman P, Nuamsiri W. 2017. Species checklist and abundance of birds in salt field areas and aquaculture areas along the coastal land, Bang Kaew Sub-district, Muang District, Samut Songkhram Province. Suan Sunandha Sci Technol J 4 (2): 13-16.

Clemens RS, Herrod A, Weston MA. 2014. Lines in the mud: revisiting the boundaries of important shorebird areas. J Nat Conserv 22: 59-67.

Cook WM, Lane KT, Foster BL, Holt RD. 2002. Island theory, matrix effects and species richness patterns in habitat fragments. Ecol Lett 5 (5): 619-623.

Dahl TE, Johnson CE. 1991. Wetlands status and trends in the conterminous United States, mid-1970's to mid-1980's. U.S. Fish and Wildlife Service, Washington, D.C.

Dugan PJ. 1990. Wetland conservation. A review of current issues and required action. IUCN, Gland, Switzerland.

Erftemeijer PLA, Jugmongkol R. 1999. Migration of Shorebirds and Habitats in Inner Gulf of Thailand. International Wetland Foundation and Bird Conservation Society of Thailand, Bangkok.

Fairbairnkkk SE, Dinsmore JJ. 2001. Local and landscape-level influences on wetland bird communities of the prairie pothole region of Iowa, USA. Wetlands 21: 41-47.

Fernández JM, Selma MAE, Aymerich FR, Sáez MTP, Fructuoso MFC. 2005. Aquatic birds as bioindicators of trophic changes and ecosystem deterioration in the Mar Menor Lagoon (SE Spain). Hydrobiologia 550: 221-235.

Gaston K. 2000. Global patterns in biodiversity. Nature 405: 220- 227.

Ghasemi S, Zakaria M, Hazandy AH, Yusof E, Danehkar A, Rajpar MN. 2010. A review of mangrove value and conservation strategy by local communities in Hormozgan Province, Iran. J Am Sci 6 (10): 329-338.

Hansen AJ, Knight RL, Marzluff JM. 2005. Effects of exurban development on biodiversity: Patterns, mechanism and research needs. Ecol Appl 15: 1893-1905.

Hattori A, Mae S. 2001. Habitat use and diversity of waterbirds in a coastal lagoon around Lake Biwa, Japan. Ecol Res 16: 543-553.

Hoyer MV, Canfield DEJ. 1994. Bird abundance and species richness on Florida Lakes: influence of trophic status, lake morphology, and aquatic macrophytes. Hydrobiologia 279/280: 107-119.

Humphries CJ, Williams PH, Wright RV. 1995. Measuring biodiversity value for conservation. Ann Rev Ecol Syst 26: 93-111.

International Union for Conservation of Nature. 2016. The IUCN Red List of Threatened Species. http://www.iucnredlist.orgl.

Ismail A, Rahman F, Zulkifli SZ. 2012. Status, composition and diversity of avifauna in the artificial Putrajaya wetlands and comparison with its two neighboring habitats. Trop Nat Hist 12 (2): 137-145.

Jae-Pyoung Y, Seon-Deok J, Wan-Byoung K, Jung-Hoon K, In-Kyu K, Tae-Han K, Seung-Woo H, Chi-Young P, Hui-Bae J, Jun-Tae C, Woon-Kee P. 2013. Characteristics of birds community in Ulleung Island Korea. J Asia-Pac Biodiv 6 (1): 175-187.

John PWK, Trirach P, Teerayuth L. 2012. Bangpu: Thailand's first urban nature education centre. Nat Hist Bull Siam Soc 58: 7-17.

Jukmongkol R. 2002. Birding sites in Thailand. Sarakadee Press, Bangkok.

Kamnung K, Suppadit T. 2015. The environmental factors that affect to species and population of waterbird around Bangpu Recreation Center, Samutprakarn Province. J Wildlife Thailand 22 (1): 9-22.

King B, Woodcock M, Dickinson EC. 1975. A field guide to the birds of South-East Asia. Collins, London.

Kober K. 2004. Foraging ecology and habitat use of wading birds and shorebirds in the Caete Bay, Northeast Para, Brazil. [Thesis]. Bremen University, Bremen.

Kostecke RM, Smith LM, Hands HM. 2005. Macroinvertebrate response to cattail management at Chyenne Bottoms, Kanas, USA. Wetlands 25: 758-763.

Lameed GA. 2011. Species diversity and abundance of wild birds in Dagona-Waterfowl Sanctuary Borno State, Nigeria. Afr J Environ Sci Technol 5 (10): 855-866.

Landesman L. 1994. Negative impacts of coastal aquaculture development. World Aquacult Soc 25: 12-17.

Leberg PL, Green MC, Adams BA, Purcell KM, Luent MC. 2007. Response of waterbird colonies in Southern Louisiana to recent drought and hurricanes. Anim Conserv 10: 502-508. 
Lee P, Rotenberry JT. 2005. Relationships between bird species in forested habitats of Eastern North America. J Biogeogr 32: 11391150.

Lee TM, Sodhi NS, Prawiladilaga DM. 2007. The importance of protected areas for the forest and endemic avifauna of Sulawesi (Indonesia). Ecol Appl 17 (6): 1727-1741.

Lekagul B, Round PD. 2006. A guide to the birds of Thailand. Saha Karn Bhaet Group, Jatujak, Bangkok.

Liang SH, Shieh BS, Fu YS. 2002. A structural equation model for physiochemical variable of water, benthic invertebrates, and feeding activity of waterbirds in the Sitsao wetlands of Southern Taiwan. Zool Stud 41: 441-451.

Ludwig JA, Reynold JF. 1988. Statistical ecology; a primer on methods and computing. Wiley Interscience Publication, New York.

Ma ZJ, Tang SM, Lu F, Chen JK. 2002. Chongming Island: a less important shorebird stopover site during southward migration? Stilt 41: 35-37.

Mardiastuti A, Mulyani YA, Dewi LK. 2016. Diversity and abundance of avian community at coastal lagoons in Bukit Barisan Selatan National Park, Indonesia: Why waterbird was lacking? The International Wildlife Symposium, University of Lampung, Bandar Lampung.

Mardiastuti A. 1992. Habitat and nest-site characteristics of waterbirds in Pulau Rambut Nature Reserve, Jakarta Bay, Indonesia. [Dissertation], Michigan State University, Ann Arbor, MI.

Marsden SJ, Whiffen M, Galetti M. 2001. Bird diversity and abundance in forest fragments and Eucalyptus plantation around an Atlantic forest reserve, Brazil. Biodiver Conserv 10 (5): 737-751.

Mckinney ML. 2002. Urbanization, biodiversity, conservation. Bioscience 52 (10): 883-890.

Murray NJ, Fuller RA. 2015. Protecting stopover habitat for migratory shorebirds in East Asia. J Ornith 156: 217-225.

Nakwa A, Sitasauwan N, Jatisatein A, Chantaramongko P, Pupichit W, Srisak P. 2008. The effects of tourists on bird diversity in tourist areas compared to restricted area of seasonal evergreen forest at Tung Salang Luang National park, Phetchabun Province, Thailand. Intl J Zool Res 4 (2): 95-105.

Nguyen PBH, Nguyen VH, Doan VN, Nguyen HMH, Nguyen NT, Pham QD, Truong ND, Vo TMT. 2009. Grassland birds survey and correlations between grassland birds and their habitat variables in Tram Chim National Park for the Rufford Small Grants for Nature Conservation, London.

Nichols FH, Thompson JK. 1985. Persistence of an introduced mudflat community in South San Francisco Bay, California. Mar Ecol 24: 8397.

Novacek MJ, Wheeler QD. 1992. Introduction. Extinct taxa: accounting for $99.999 . . . \%$ of the Earth's biota. In: Novacek MJ, Wheeler QD (eds.). Extinction and Phylogeny. Columbia Univ. Press, New York.

Office of Natural Resources and Environmental Policy and Planning (ONEP). 2007. Thailand Red Data: Vertebrates. Ministry of Natural Resources and Environment, Bangkok, Thailand.
Park JY, Kim DW, Choi YS, Nam KB, Kwon YS, Kim MR, Moon YM 2012. Seasonal variation study of the migratory birds in Ulleungdo; Proceeding of the Ornithological Society of Korea Conference, Seoul.

Petersen KL, Westmark AS. 2013. Bird use of wetlands in a Midwestern Metropolitan area in relation to adjacent land cover. Amer Midland Nat J 169 (1): 221-228.

Pettingill OS. 1969. A laboratory and field manual of ornithology. Burgess Publishing Company, Minnesota.

Remsen JV, Parker TA. 1983. Contribution of river-created habitats to bird species richness in Amazonia. Biotropica 15 (3): 223-231.

Salah O, Idris E. 2013. A note on the bird diversity at two sites in Khartoum, Sudan Egypt. Egypt Acad J Biol Sci 5 (1): 1-10.

Schrag AM, Zaccagnini ME, Calamari N, Canaveli S. 2009. Climate and land-use influences on avifauna in central Argentina: broad-scale patterns and implications of agricultural conversion for biodiversity. Agric Ecosyst Environ 132 (1-2): 135-142.

Scott A. 1997. The cultural economy of cities. Int J Urban Reg Res 21 (2): 323-339.

Scott DA. 1980. A preliminary inventory of wetlands of international importance for waterfowl in West Europe and North-west Africa. International Waterfowl and Wetlands Research Bureau, Slimbridge, UK.

Sisk TD, Launer AE, Switky KR, Ehrlich PR. 1994. Identifying extinction threats: global analyses of the distribution of biodiversity and the expansion of the human enterprise. In: Ecosystem Management. Springer, New York.

Stewart RE. 2007. Wetlands as bird habitat. United States Geological survey water. United States Geological Survey Water Supply Paper 2425, USGS, Washington DC.

Tavares DC, Siciliano S. 2014. The bird community in a threatened coastal lagoon in Southeastern Brazil. Open J Ecology 4: 98-112.

Varasteh MH, Zakaria M. 2009. Insectivorous bird community change along an edge-interior gradient in an isolated tropical rainforest in Peninsular Malaysia. Malaysian Nat J 61 (1): 48-66.

Walwert M, Mardiastuti A, Muhlenberg M. 2004. Effects of land use on bird species richness in Sulawesi, Indonesia. Conserv Biol 18: 13391346.

Welsh DA. 1987. Birds as indicators of forest stand condition in bored forest of Eastern Canada. In: Diamond AW and Filion FL. The value of birds. International Council for Bird Preservation, Cambridge, England.

Wetlands International. 2012. Waterbird Population Estimates 5th ed. Wetlands International, Wageningen, Nederlands. http://wpe.wetlands.org.

WWF. 2007. Thailand together with the Royal Thai Army opens Bang Pu Nature Education Center. WWF, Thailand.

Zedler JB, Kercher S. 2005. Wetland resources: status, trends, ecosystem services, and restorability. Ann Rev Environ Resour 30: 39-74.

Zou F, Zhang H, Dahmer T, Yang Q, Cai J, Zhang W, Liang C. 2008. The effects of benthos and wetland area on shorebird abundance and species richness in coastal mangrove wetlands of Leizhou Peninsula, China. For Ecol Manag 255: 3813-3818. 